ACTA AGROBOTANICA

Vol. 59, z. 12006

s. 301308

\title{
The phenology of flowering and fluctuations of airborne pollen concentrations of selected trees in Poznań, 2003-2004
}

\author{
ALICJA STACH ${ }^{1}$, MAGDALENA KLUZA-WIELOCH ${ }^{2}$, \\ ALICJA ZIENTARSKA ${ }^{3}$ \\ ${ }^{1}$ Laboratory of Aeropalynology Adam Mickiewicz University, \\ ul. Umultowska 89, 61614 Poznań \\ ${ }^{2}$ Botany Department Agriculture University, Poznań, \\ ul. Wojska Polskiego 71C, 60625 Poznań \\ ${ }^{3}$ Forest Botany Department Agriculture University, Poznań, \\ ul. Wojska Polskiego 71D, 60625 Poznań
}

(Received: 29.05.2005)

\section{S u m m ary}

The aim of the study was to describe the relationships between the flowering phase of selected tree species, whose pollen is known to be allergenic, and fluctuations in the pollen in the air, and to use results obtained for making allergological forecasts.

Studies were conducted of five tree taxa: Populus, Ulmus, Salix, Aesculus, and Tilia, in the years 2003-2004. Aeropalinological analyses concerned the above mentioned genera, while in phenological studies specific species were investigated, i.e. the most common representatives of a given genus found in Poland, that is Populus wilsonii, Ulmus laevis Pall. C. K.Schneid., Salix caprea L., Aesculus hippocastanum L. and Tilia cordata Mill.

Aerobiological monitoring was performed using a the volumetric method and phenological observations of flowering phases were made according to the Łukasiewicz method.

While observing the emergence of individual phenological symptoms and measurements of the concentration of pollen of the investigated taxa in the air of Poznan, a distinct acceleration was observed in 2004, a year that was characterized by a milder winter. This applied not only to the species blooming in early spring, but also to the later ones. Pollen grains of the investigated taxa, except for Aesculus, appeared earlier in aeropalinological observations than the macroscopically observed beginning of flowering in selected trees. Apart from a poplar, the end of flowering in the other trees occurred each year earlier than would follow from the aerobiological observations. This may be explained by the abundance of species within a taxon, and the effect of medium and long-distance transport. 


\section{INTRODUCTION}

Increasing incidences of allergies caused by allergens of plant pollen and fungal spores have recently been observed, and have given rise to enhanced interest in this problem (D'A m at o et al., 1998; B o n in i, 1999). For several years now, studies have been conducted for the purpose of allergological research in numerous countries, including Poland, on the contents of bioaerosols in the outside air (S z c z e p a n e k et al., 1995). It has been known that the occurrence and changes in microspore concentrations of allergenic plant and fungal species depend to a large extent on weather conditions. Apart from detailed studies on aeroplankton, phenological observations of flowering phases seems to be very helpful in the assessment of the beginning, peak-and end of the pollen discharge season.

The aim of the study was to describe the relationships between the flowering phase of selected trees and shrub species, whose pollen is known to be allergenic, and fluctuations in the pollen in the air. The applied aim of the study was to include these relationships for making allergological forecasts. Attempts are made to show that systematic phenological studies, connected with weather observations, will make it possible to predict more precisely when increased allergological risk may occur. For several years now, two independent teams in the city of Poznan have been conducting aeropalinological studies ( $\mathrm{Stach}, 2002 ; \mathrm{Stach}$ et al., 2002) and phenological observations (K lu za and Zientarska, 1999a, b). In 2003 studies of Corylus, Betula and Quercus (S tach et al., 2004) were undertaken. The outcomes of the present studies will constitute the baseline for a more comprehensive methodology and the direction of further cooperation between aerobiologists and phenologists.

\section{MATERIAL AND METHODS}

The studies were conducted in the years 2003-2004. The five tree taxa, used as comparative material, are listed in the order of the appearance of their allergenic pollen: Populus, Ulmus, Salix, Aesculus, and Tilia. Moreover, the first two are anemophilous, the third is entomo and anemophilous, and the last two are entomophilous. Aeropalinological analyses concerned the above mentioned genera, while in phenological studies specific species were investigated, i.e. the most common representatives of a given genus found in Poland, that is Populus wilsonii, Ulmus laevis Pall.C.K.Schneid., Salix caprea L., Aesculus hippocastanum L. and Tilia cordata Mill.

Aerobiological monitoring was performed using a volumetric trap (Hirst, 1952) located in the city centre at the height of $36 \mathrm{~m}$ above the ground level. Pollen discharge seasons were determined on the basis of the International Association for Aerobiology findings ( $\mathrm{J}$ ä g e r , 2003). Phenological observations of flowering phases were made according to $Ł$ u k a s i e w i c z (1984) in the Dendrological Garden of the Agricultural University of Poznań, located approx. $2.5 \mathrm{~km}$ north of the aerobiological measurement point. Out of the whole phenological spectrum only a part of the generative phase was used, i.e. the phase of buds of flowers and the phase of flowering. The 
emergence of the following phenomena were used to determine this fragment of the spectrum: the emergence of male buttons of flowers, the beginning of flowering, full flowering, the first overblown flowers, the last flower buttons, the end of full flowering and the end of flowering. The emergence of the signs of the beginning of flowering, full flowering and the end of flowering proved useful for the purpose of comparison with aeropalinological studies.

The investigations were related to the weather conditions with special emphasis on the temperature and precipitation. Meteorological data were taken from the monthly survey of meteorological data „Miesięczny Przegląd Agrometeorologiczny” (Table 1). While characterizing weather components in the years of observations, in the period of flowering and the time preceding it, it was found that the year 2003 was much cooler than 2004. The 2003 winter was long and frosty. In the first quarter subzero mean monthly temperatures and low precipitation were observed. Minimum temperature at the ground dropped to $-25^{\circ} \mathrm{C}$. This resulted in delayed plant vegetation. A lowering in the temperature in March, and March and April ground frosts had only a slight inhibitory effect on the development of plants. In successive months no

Table 1

Meteorological data (monthly average temperature $\left[{ }^{\circ} \mathrm{C}\right]$ and total precipitation $[\mathrm{mm}]$ ) in the years 2003, 2004 and mean of 19511990.

\begin{tabular}{|l|c|c|c|c|c|c|}
\hline \multirow{2}{*}{ Months } & \multicolumn{3}{|c|}{ Temperature $\left({ }^{\circ} \mathrm{C}\right)$} & \multicolumn{3}{c|}{ Precipitation (mm) } \\
\cline { 2 - 7 } & 2003 & 2004 & $\begin{array}{c}\text { Mean of } \\
1951-1990\end{array}$ & 2003 & 2004 & $\begin{array}{c}\text { Mean of } \\
1951-1990\end{array}$ \\
\hline January & -1.7 & -4.0 & -2.0 & 49.1 & 52.6 & 29 \\
\hline February & -3.5 & 1.6 & -1.3 & 4.9 & 23.7 & 25 \\
\hline March & 3.0 & 4.7 & 2.5 & 13.0 & 18.9 & 27 \\
\hline April & 8.2 & 9.4 & 7.5 & 20.4 & 18.3 & 36 \\
\hline May & 15.7 & 12.5 & 13.1 & 6.1 & 51.1 & 50 \\
\hline June & 19.0 & 16.0 & 16.7 & 23.4 & 55.4 & 61 \\
\hline July & 19.5 & 18.0 & 18.0 & 125.0 & 48.0 & 73 \\
\hline August & 19.4 & 19.9 & 17.2 & 7.2 & 56.1 & 57 \\
\hline September & 14.7 & 14.3 & 13.4 & 19.1 & 24.6 & 43 \\
\hline October & 5.8 & 10.5 & 8.8 & 33.5 & 36.6 & 36 \\
\hline November & 5.6 & 4.2 & 3.6 & 20.1 & 46.1 & 36 \\
\hline December & 1.9 & 1.7 & 0.1 & 23.2 & 33.2 & 38 \\
\hline Mean/total & 9.0 & 9.1 & 8.1 & 345 & 464.6 & 511 \\
\hline
\end{tabular}

larger deviations from the mean multiannual monthly temperature and precipitation totals were found, only July was characterized by exceptionally high rainfall (125 $\mathrm{mm})$. Summing up, precipitation total $(345 \mathrm{~mm})$ constituted only $60 \%$ multiannual total $(571.5 \mathrm{~mm})$, while the mean annual temperature was $9^{\circ} \mathrm{C}$ and was equal to the multiannual mean. The winter in 2004 was mild. Minimum ground temperature was not lower than $-19^{\circ} \mathrm{C}$. February was warmer than in the previous year, with high precipitation total, which resulted in accelerated plant vegetation. March, April and May ground frosts caused an inhibition of blooming and elongation of successive phenophases. Summer was warm and rather wet. No climatic anomalies were observed. Summing up, the precipitation total was $464.6 \mathrm{~mm}$, whereas mean annual temperature was $9.1^{\circ} \mathrm{C}$. 


\section{RESULTS}

A tendency was found for earlier flowering when comparing 2004 with the year before. The poplar started and finished the process of flowering earlier than in the preceding year 2003. Pollen grains of this taxon were reported earlier than flowers in every year. Full flowering, corresponding to the maximum of the pollen discharge season, was identical to in the first year of the study, while in the second year it was observed earlier. In contrast, the end of flowering was recorded later than the last pollen records. In the next season poplar pollen was present in the air for a longer time.

In the first year of the study, the occurrence of pollen grains of the elm was recorded later than implied by phenological observations, while in the second year pollen grains were observed earlier. Every year the maximum of the pollen production season and its end came later in relation to phenological observations.

Also the willow bloomed earlier in 2004 than in 2003. In both years of the study its pollen was detected earlier in the air and the height maximum of the pollen discharge season came later.

The flowering of the chestnut began earlier in the warmer year of 2004 and lasted longer than in the previous year. In 2003 pollen of this taxon was recorded earlier than the flowering process was observed, and the maximum and end of the

Table 2

Phenological symptom and aerobiological data for selected taxa in Poznań, 2004.

\begin{tabular}{|c|c|c|c|c|c|c|c|c|c|c|c|c|}
\hline \multirow{2}{*}{ Species } & \multirow{2}{*}{ Year } & \multicolumn{7}{|c|}{ A. Phenologicalsymptoms } & \multicolumn{4}{|c|}{ B. A erobiological results } \\
\hline & & 1 & 2 & 3 & 4 & 5 & 6 & 7 & 8 & 9 & 10 & 11 \\
\hline \multirow[t]{2}{*}{ Populus wilsonii } & 2003 & 24.03 & 14.04 & 17.04 & 22.04 & 28.04 & 24.04 & 30.04 & 29.03 & 17.04 & 25.04 & 890 \\
\hline & 2004 & 18.03 & 01.04 & 05.04 & 13.04 & 19.04 & 08.04 & 26.04 & 15.03 & 13.04 & 22.04 & 625 \\
\hline \multirow[t]{2}{*}{ Ulmus laevis } & 2003 & 24.03 & 27.03 & 31.03 & 07.04 & 17.04 & 10.04 & 22.04 & 30.03 & 17.04 & 28.04 & 176 \\
\hline & 2004 & 18.03 & 25.03 & 29.03 & 08.04 & 13.04 & 01.04 & 15.04 & 19.03 & 04.04 & 18.04 & 122 \\
\hline \multirow[t]{2}{*}{ Salix caprea } & 2003 & 2002 & 14.04 & 17.04 & 22.04 & 28.04 & 24.04 & 30.04 & 28.03 & 01.05 & 10.05 & 390 \\
\hline & 2004 & 2003 & 29.03 & 01.04 & 08.04 & 13.04 & 05.04 & 15.04 & 25.03 & 29.04 & 10.05 & 365 \\
\hline \multirow{2}{*}{$\begin{array}{l}\text { Aesculus } \\
\text { hippocastanum }\end{array}$} & 2003 & 10.04 & 02.05 & 05.05 & 09.05 & 5.05 & 12.05 & 26.05 & 30.04 & 17.05 & 17.06 & 44 \\
\hline & 2004 & 08.04 & 26.04 & 29.04 & 06.05 & 17.05 & 13.05 & 31.05 & 28.04 & 06.05 & 21.06 & 77 \\
\hline \multirow[t]{2}{*}{ Tilia cordata } & 2003 & 19.05 & 09.06 & 16.06 & 23.06 & 30.06 & 23.06 & 07.07 & 05.06 & 24.06 & 22.07 & 97 \\
\hline & 2004 & 06.05 & 17.06 & 01.07 & 05.07 & 15.07 & 08.07 & 19.07 & 20.06 & 30.06 & 05.08 & 71 \\
\hline
\end{tabular}

A. Phenological symptoms: 1 buds of flower, 2 beginning of flowering 3 full flowering, 4 first of flower blossoms, 5 end of full flowering, 6 last buds of flower, 7 end of flowering.

B. Aerobiological results: 8 start of season, 9 seasonal maximum, 10 end of season, 11 Seasonal Pollen Index. 
pollen discharge season came later, both in that and in the successive year. In 2004 flowering was observed earlier than the presence of pollen in the air.

However, in the case of the linden, the process of flowering began earlier in 2003. Pollen was observed each year earlier in comparison to phenological observations. Full flowering in the first year of this study was reported sooner than the maximum pollen content detected in the air, while in the second year they corresponded in time. The end of flowering came earlier than the end of the pollen discharge season.

Higher values of annual pollen totals were observed in Populus, Salix and Ulmus (Table 2). In the investigated period in Poznan willow pollen was more abundant than that of elm. Higher annual totals of pollen grains were recorded in 2003 in Populus, Ulmus, Salix and Tilia, in case of Aesculus the pollen grain total was higher in 2004.

\section{DISCUSION}

In Europe simultaneous aerobiological and phenological studies have been conducted by teams of researchers from Italy (Zan otti and Puppi, 2000). The only Polish phenological and aerobiological studies for 3 tree species were conducted in Rzeszów by K a s p z y k (2003). The studies carried out in Poznań are primarily intended to aid the preparation of allergological forecasts.

Pollen grains of the tree taxa included in this study exhibit lower allergenicity than for example the pollen of alder, birch or oak trees, although the risk imposed should not be underestimated (Lew is et al., 1983; D ominguezet al., 1984; J a to et al., 2001).

In the period under analysis, poplar pollen, although it reached the highest annual totals in comparison to the other investigated taxa, still did not reach the value found in Poznań in 1996 ( $\mathrm{S} \mathrm{ta} \mathrm{c} \mathrm{h} \mathrm{,} \mathrm{2002).} \mathrm{In} \mathrm{that} \mathrm{year} \mathrm{the} \mathrm{annual} \mathrm{total} \mathrm{was} \mathrm{three} \mathrm{times}$ higher than that recorded in 2003.

Willows belong to anemo and entomophilous plants (S u s z k a, 1990) and although they do not produce large amounts of pollen (Ch a u p ka, 1990), the annual pollen totals in both years of the study were two and three times higher than the totals for the anemophilous Ulmus in the same years. In case of Populus and Salix, higher annual pollen totals may be explained by the abundance of the species of the given taxon found in Poznań and the number of specimens within the city and outside the city limits.

Linden is found quite frequently in street plantings and in parks of Poznań, but its pollen was observed in rather small amounts, not only in the analyzed period, but also earlier ( $\mathrm{S} \mathrm{t} \mathrm{a} \mathrm{c} \mathrm{h} \mathrm{,2002).} \mathrm{This} \mathrm{results} \mathrm{primarily} \mathrm{from} \mathrm{the} \mathrm{fact} \mathrm{that} \mathrm{Tilia} \mathrm{is} \mathrm{an} \mathrm{entomo-}$ philous plant and has large pollen grains. Observations conducted at various altitudes (Har t et al., 1994) showed that at the altitude above $30 \mathrm{~m}$ Tilia pollen was scarcely found. Low values of annual totals for linden in different cities were also observed by other researchers, e.g. S z c z e p a n e k (1994), K a s p r z y k (1996). If in Poznań at the altitude of $36 \mathrm{~m}$ linden pollen is often recorded, it may be assumed that at the 
"nose height" of an allergic patient it may reach much higher concentrations. A similar phenomenon may occur in case of Aesculus. During the full flowering of chestnut trees, the allergenic threat posed by this taxon is probably higher than observations conducted on the roof would suggest.

The largest discrepancy between phenological and aerobiological observations, concerning the beginning of the pollen discharge season and the beginning of flowering, was observed in Populus and Salix. This results from the fact that aerobiological data include pollen grains of all Populus or Salix species growing in the city of Poznan and in the Wielkopolska region, whereas phenological observations are limited to one specific species. The earliest poplar pollen grains detected on the tapes of the volumetric trap are probably pollen grains of Populus tremula, which appear in the air earliest.

The occurrence of pollen grains in the air after the completion of flowering in the phenologically analyzed specimens indicates the medium and long-distance transport, discussed in previous studies ( $\mathrm{Stach}, 2002 ; \mathrm{Stach}$ et al., 2002).

\section{CONCLUSIONS}

While observing the emergence of individual phenological symptoms and measurements of the concentration of pollen of the investigated taxa in the air of Poznan, a distinct acceleration was observed in 2004 , a year that was characterized by a milder winter. This applied not only to the species blooming in early spring, but also to the later ones.

Pollen grains of the investigated taxa, except for Aesculus, appeared earlier in aeropalinological observations than the macroscopically observed beginning of flowering in selected trees.

Apart from poplar, the end of flowering in the other trees occurred each year earlier than would follow from the aerobiological observations. This may be explained by the abundance of species within a taxon, and the effect of medium and longdistance transport.

In the case of anemophilous trees, much larger amounts of pollen were observed in the air than in willows and taxa pollinated only by insects.

Conducting detailed observations of the beginning of the flowering phase in relation to the weather conditions may facilitate the prediction of the beginning and full pollen discharge season in allergenic tree and shrub species. Better temporal resolution of the weather observations will help in making possible relationships more evident. Further studies are still required in this respect.

\section{Acknowledgements}

This work was partly supported by interuniversity project AMU AR, PU-II/56 and AEROTOP MTKD-CT-2004-003170

To Professor Roger Bivand for English correction. 


\section{LITERATURE}

B o n in i S., 1999. Allergic diseases: a major health problem for the next millennium. Int Rev Allergol Clin Immunol. 5 (3): 99100.

D'A m a t o G., L i c c a r d i G., R u s s o M., 1998. Update in interrelationship between air pollution and respiratory allergy. $6^{\text {th }}$ International Congress on Aerobiology. Perugia Italy, 31 August 5 September 1998: 2429.

$\mathrm{C}$ h a $\nmid$ u p k a W., 1990, Wybrane zagadnienia wzrostowe i rozwojowe [Selected problems of growth and development]. In: Białobok S. (ed.) Nasze drzewa leśne, Wierzby, Monogra fie Popularnonaukowe [Our forest trees, Willows, Popular Science Studies] PWN, War szawa Poznań pp: 6170.

D o m i ng u e z E., U b e r a J. L. \& G a 1 a n C., 1984. Polen alergogeno de Córdoba. Publicationes del Monte Piedad y Caja de Ahorros de Ronda. Córdoba.

Hart M. L., W e n t w or th J. E., B a i l e y J. P., 1994. The effects of trap height and weather variables on recorded pollen concentration at Leicester. Grana, 33: 100103.

H i r s t J. M., 1952, An automatic spore trap. Ann. Appl. Biol. 39: 257265.

Jato Rodriguez V., Iglesias Fernandez I., AiIra Rodriguez M. J. 2001. Atlas de polen alergógeno. Xunta de Galicia: 244.

J ä g e r S. 2003. The European Pollen Information System (epi). Data bank (EAN), Web sites and forecasting. Postepy Dermatologii I Alergologii XX, 4: 239243.

K a s p r z y k I., 1996. Palynological analysis of airborne pollen fall in Ostrowiec Świętokrzyski in 1995. Ann. Agric. Environ. Med. 3, 2: 8386.

$\mathrm{K}$ a s p r z y k I., 2003. Flowering phenology and airborne pollen grains of chosen tree taxa in Rzeszów (SE Poland). Aerobiologia, 19: 113120.

K 1 u z a M., Z i e n t a r s k a A., 1999a. Obserwacje fenologiczne fazy kwitnienia wybranych gatunków krzewów w Ogrodzie Dendrologicznym Akademii Rolniczej w Poznaniu [Phe nological observations of the flowering phase in selected shrub species in the Dendrologi cal Garden of the Agricultural University of Poznań]. Bibliotheca Fragmenta Agronomi ca, 6: 117124 .

K 1 u z a M., Z i e n t a r s k a A., 1999b. Obserwacje fenologiczne wybranych gatunków drzew i krzewów z rodziny Celastraceae i Rosaceae introdukowanych w Ogrodzie Dendrologicz nym Akademii Rolniczej w Poznaniu [Phenological observations of selected tree and shrub species from families Celastraceae and Rosaceae introduced in the Dendrological Garden of the Agricultural Uiversity of Poznań]. Rocz. AR Pozn. CCCIX, Bot. 1: 3154.

L e w i s W. H., V i n a y P. \& Z e n g e r V.E., 1983. Airborne and allergenic pollen of North America. The Johns Hopkins University Press, Baltimore.

Ł u k a s i e w i c z A., 1984. Potrzeba ujednolicenia metodyki fenologicznej w polskich ogrodach botanicznych i arboretach [The need to unify phenological methodology in Polish botani cal gardens and arboreta]. Wiad. Bot. 28, 2: 153158.

Mi es i ęc zny Przeglą d A gromete or ol og i c z n y 112 (2003, 2004). Instytut Meteorologii i Gospodarki Wodnej, Warszawa.

S t a c h A. 2002. Pyłek roślin w aeroplanktonie Poznania w latach 19941997 ze szczególnym uwzględnieniem pyłku roślin taksonów alergogennych [Plant pollen in aeroplankton of the city of Poznań in the years 19941997 with special emphasis on pollen of allergenic taxa]. Doctoral dissertation, copy in the archives of the Institute of Botany, the Jagiellonian University p. 164.

S t a ch A., C z a r n e c k a O peracz M., N ow a c z y k B., S i 1 n y W., 2002. Wpływ warunków pogodowych na przebieg sezonów pyłkowych wybranych alergogennych taksonów w Poznaniu w 2000 roku [The effect of weather conditions on pollen seasons of selected allergenic taxa in Poznań in 2000]. Annales, 2002, X, 139146. 
S t a c h A., K l u z a W i e lo c h M., Z i e n t a r s k a A., 2004. The phenology of flowering and airborne pollen concentrations of selected trees In Poznań, (Poland), 19951997. Polen, 14: 346347.

S z c z e p a n e k K., 1994. Pollen calendar for Cracow (Southern Poland) 1982 1991. Aerobio logia, 10, 1: 6570 .

S z c z e p a ne k K., H a r m a t a K., K a s p r z y k I., M y s z k ow s ka D., S t a c h A., $\mathrm{S}$ tę palska D., 1995. For reliable net of measurment of pollen and fungal spores occurrence in the air of Poland. [W:] Pollen and Pollinosis: Current problems. [Red.] R. Śpiewak, Institute of Agricultural Medicine, Lublin, Poland: 1617.

S u s z k a B., 1990. Rozmnażanie generatywne i wegetatywne [Generative and vegetative reproduction]. In: Białobok S. (ed.) Nasze drzewa leśne, Wierzby, Monografie Popular nonaukowe [Our forest trees, Willows, Popular Science Studies]. PWN, Warszawa Poznań pp: 161210.

Z a n o t t i A. L., P u p p i G., 2000. Phenological surveys of allergenic species in the neighborhood of Bologna (Italy). Aerobiologia, 16: 199206.

\section{Fenologia kwitnienia i wahania stężenia pyłku wybranych drzew w powietrzu Poznania w latach 2003-2004}

\section{Streszczenie}

Celem badań było wykazanie związku pomiędzy wynikami monitoringu fazy kwitnienia wybranych gatunków drzew, których pyłek działa uczulająco, a wahaniami zawartości aeroplanktonu w powietrzu oraz ich wykorzystaniu w przygotowaniu prognoz dla potrzeb alergologicznych.

W latach 2003-2004 badano pięć taksonów drzew: Populus, Ulmus, Salix, Aesculus, i Tilia. Analizy aeropalinologiczne dotyczyły podanych rodzajów, a w obserwacjach fenologicznych badano konkretne gatunki, często występujących w Polsce przedstawicieli danego rodzaju: Populus wilsonii C. K. Schneid., Ulmus laevis Pall., Salix caprea L., Aesculus hippocastanum L. i Tilia cordata Mill.

Monitoring aerobiologiczny prowadzono aparatem wolumetrycznym a obserwacje fenologiczne faz kwitnienia wykonywano metodą Łukasiewicza.

Obserwując poszczególne pojawy fenologiczne oraz zawartość pyłku badanych taksonów w powietrzu Poznania, stwierdzono wyraźne ich przyspieszenie w roku 2004, cechującym się łagodniejszą zimą. Dotyczyło to nie tylko gatunków zakwitających wczesną wiosną, ale również i tych późniejszych. Ziarna pyłku badanych taksonów, oprócz Aesculus, pojawiały się wcześniej w obserwacjach aeropalinologicznych, niż makroskopowo obserwowano początek kwitnienia wybranych drzew. $\mathrm{Z}$ wyjątkiem topoli, koniec kwitnienia pozostałych drzew przypadał rokrocznie wcześniej niż wynikało to z badań aerobiologicznych. Przyczynę tego można tłumaczyć bogactwem gatunków w obrębie taksonu oraz wpływem średniego i dalekiego transportu. Kontynuacja wspólnych badań może pomóc w prognozowaniu początku i pełni sezonu pyłkowego alergogennych gatunków drzew i krzewów, pod warunkiem, że badania będą prowadzone przez wiele lat. 